\title{
PHOSPHATE RELATIONSHIPS IN ACID-SULPHATE SOILS OF MBIABET SWAMP RICE FARM, AKWA IBOM STATE, NIGERIA.
}

W. UBI AND V. E. OSODEKE

(Received 29 September , 2008; Revision Accepted 31 March, 2009)

\begin{abstract}
A study was conducted in April 2006 to determine the phosphate relationship in acid sulphate soils of Mbiabet Swamp Rice farm in Akwa lbom State, Nigeria. Soil samples were collected in the order of $0-1,1-2,2-5,5-8,8$ - 10 and $10-15 \mathrm{~cm}$ soil depths. Treatments consisted of potassium dihydrogen phosphate added to the swamp mud, cat-clay, and mud-clay in equal doses of $122 \mathrm{~kg} / \mathrm{ha} \mathrm{P}_{2} \mathrm{O}_{5}$, fitted into Latin square of $36 \times 5 \mathrm{~m}$ swamp, except for the control plots. Limestone $\left(\mathrm{CaCO}_{3}\right)$ was applied to both fertilized and unfertilized plots at the rate of $50 \mathrm{~kg} / \mathrm{ha}$ to reduce the activity of alumimium. The distribution of phosphate in the top $10 \mathrm{~cm}$ of unfertilized plots at the fresh and dried mud showed that the bulk of the total phosphorus was in the organic and occluded forms. There was no saloid-bound phosphorus present in either the fresh or dried mud. The fixation of phosphorus was rapid, reaching the equilibrium within 50 - 75 hours. Fresh mud (except cat-clay) absorbed more phosphate than did dried mud and nearly 60 percent of the absorption took place within 6 hours. The soluble phosphate applied as solution to columns of air-dried swamp mud showed a decrease within 6 months, but calcium and organic phosphate increased. Saloid-bound phosphate with the water-logged cat-clay decreased considerably. The soils have great opportunities in rice production when given proper soil management.
\end{abstract}

KEYWORDS: Soil, Swamp Rice Farm and Phosphate

\section{INTRODUCTION}

The soils of marine flood plains are basically said to be acid sulphate soils. Such soils, upon drainage and aeration, show definite and severe acidification as a result of the oxidation of sulphides (mainly pyrite, $\mathrm{FeS}_{2}$ ) which may lead to the formation of sulphuric acid. These soils are not limited to marine flood plains exclusively, but other soils that bear $\mathrm{FeS}_{2}$ deposits inland may equally show the same phenomenon (Moorman, 1963, Hue and Amien 1990, Enwezor and Moore 1996, Ubi and Osodeke 2007).

Van-der Spek (1950) earlier used the term "catclay" to denote acid soil material in its oxidized form showing straw-yellow mottling and streak of basic ferric sulphate, while Edelman et al (1958), proposed the term "mud-clay" to denote the non-drained, unoxidised soil with a high potential acidity. Both forms of acid sulphate soils are of fairly widespread occurrence along the coastal and riverine regions of Akwa Ibom State.

The possibility of using these soils for swamp rice cultivation however, engaged the attention of the Niger Delta Development Commission (NDDC), since the swamp had been used for rice cultivation by farmers in the area for more than twenty years.

The lime requirements of these soils are usually high and drainage costly, thus reclamation is often uneconomical. Some fertilizer trials carried out in a Latin square of $36 \times 1$ ha swamp (Clarkson, 1996, Abruna et al 1975, Havlin et al 2006, Ubi and Osodeke 2007) showed that when the reaction of both soil and treatments were maintained at about neutrality, phosphorus was one of the chief limiting factors in the good performance of the crop from these soils. This finding is in accordance with the now generally accepted fact that phosphate deficiency could be wide spread and distinct in acid-sulphate soils. Other researchers also demonstrated that a protein crop could be obtained from soils of high potential acidity and low intrinsic fertility by addition of small lime and fertilizer-phosphorus applied to the soil (Brady and Weil 1999).

The present study was undertaken to obtain information hitherto lacking on the distribution of phosphorus already present in the soil and how this could be affected by drying, the phosphorus fixation capacity of the sols, effect of time on the distribution of phosphorus drying and changes in forms of phosphorus during incubation of the muds.

\section{MATERIALS AND METHODS}

The study was conducted in 2006 at Mbiabet Ini Local government area of Akwa Ibom State, Nigeria. The area is located within the humid rain forest zone with two distinct seasons, viz: the rainy and dry-season. The annual precipitation ranges from $2000-3000 \mathrm{~mm}$ per annum, and lies on Longitude $07^{\circ} 34^{1}$ and $07^{\circ} 36$ East and $05^{\circ} 29^{1}$ and $05^{\circ} 31$ North and is $125 \mathrm{~m}$ above sea level. The experimental design used was Latin square.

Treatments consisted of potassium dihydrogen phosphate added to the fresh swamp mud, cat-clay and mud-clay in equal doses of $122 \mathrm{~kg} / \mathrm{ha} \mathrm{P}_{2} \mathrm{O}_{5}$. Liming material used was $\mathrm{CaCO}_{3}$ at $50 \mathrm{~kg} / \mathrm{ha}$ to reduce activity and solubility of aluminium and iron which can be toxic in all but very low concentration. Limestone was applied to both fertilized and unfertilized swamp of the Latin square.

The soil at the experimental site was sandy loam with the following characteristics $\mathrm{pH}: 4.86$, exchangeable aluminum $2.50 \mathrm{cmol} \mathrm{kg}^{-1}$ Nitrogen $0.06 \%$, Avail. P $13.00 \mathrm{mg}$, Exchangeable calcium, magnesium and potassium were: $1.7,0.65$, and $0.16 \mathrm{cmol} \mathrm{kg}^{-1}$ respectively.

The soil samples used in the experiment were muds obtained from three sites within the swamp. The

W. Ubi, Dept of Soil Chemistry and Agro-Climatology, Micheal Okpara Univ. of Agric, Umudike, Abia State, Nigeria.

V. E. Osodeke, Dept of Soil Chemistry and Agro-Climatology, Micheal Okpara University of Agric, Umudike, Abia State, 
samples were taken from 1-1, $1-2,2-5,5-8,8-10$ and $10-15 \mathrm{~cm}$ soil depths. The mud-clay was obtained outside the actual paddy field, from the bottom of the water channel cut through swamp land, and used for bringing water to the paddy field. The cat-clay was obtained from the bunds which had been excavated during the construction of stream banks, spillways and reservoir about twenty years ago. The unfertilized swamp mud was taken from the swamp of the Latin square, swamp mud which had received a surface Limestone dressing, but no phosphate. The samples were obtained with the aid of a plastic tub, fitted with a rubber stoppered position to facilitate the extraction of the cores.

In the three soil types examined, 30 soil samples were collected, 10 per each soil type. The idea was to obtain a representative sample of the three soil types for analytical work. In the case of the values for the distribution of phosphate with depth, the analytical results for four samples bulked covered from each of 3 swamp muds were averaged.

The fractionation of the inorganic phosphorus was done by the method of Chang and Jackson (1957). Total phosphorus was determined after fusion with $\mathrm{Na}_{2} \mathrm{CO}_{3}$ and organic phosphorus was taken as the difference between the total phosphorus and the summation values of the inorganic forms obtained from the fractionation analysis. Phosphorus-fixation capacities were determined by the method of Larsen et al (1959).

\section{RESULTS}

\section{The distribution of phosphate in the top $10 \mathrm{~cm}$ of the unfertilized muds}

Phosphate distribution in the top $10 \mathrm{~cm}$ of the unfertilized fresh and dried mud is given in Table 1, from which it can be seen that the bulk of the total phosphorus was in the organic and occluded forms. The remainder was in association with calcium. In the dry mud, which over the drying period of 10 days, became more acid, occlusion of phosphate occurred in the case of the mud-clay and swamp mud. In the cat-clay occlusion of phosphate did not occur. There was no Saloid-bound phosphorus present in either the fresh or dried muds.

\section{Phosphorus Fixation Capacity}

The immobilization of added inorganic phosphorus as potassium dihydrogen phosphate by the fresh and dried muds as shown in this study was glaring. The fixation was fairly rapid, equilibrium being obtained within about $50-75$ hours. The fresh mud (with the exception of the cat-clay) absorbed more phosphate than did the dried mud and nearly 60 per cent of the absorption took place in 6 hours.

Table 1: Forms of phosphorus found in the top $10 \mathrm{~cm}$ of unfertilized muds. (Results as Mg/kg $\mathrm{P}_{2} \mathrm{O}_{5}$ Oven-dry mud).

\begin{tabular}{llll}
\hline Forms of $\mathrm{P}$ & Mud-clay & Cat-clay & Swamp mud \\
\hline Saloid-bound & 0 & 0 & 0 \\
Ca-bound & 151 & 13 & 10 \\
Occluded & 275 & 104 & 72 \\
Organic & 405 & 114 & 86 \\
\hline Total & 831 & 231 & 168 \\
\hline $\mathrm{pH}$ & 7.0 & 4.1 & 6.5 \\
\hline Dried mud & & & \\
Saloid-bound & 0 & 0 & 0 \\
Ca-bound & 96 & 10 & 7 \\
Occluded & 378 & 104 & 84 \\
Organic & 426 & 117 & 8.8 \\
\hline Total & 900 & 231 & 99 \\
\hline $\mathrm{pH}$ & 5.7 & 3.8 & 5.5 \\
\hline
\end{tabular}

The amount of phosphate expressed in $\mathrm{kg} / \mathrm{ha}$ of Triplesuperphosphate, required to saturate the fresh and dry mud to a depth of $5 \mathrm{~cm}$ is given in Table 2 . The values have been calculated for a fertilizer containing 40 per cent phosphorus pentoxide.

Table 2: Amount of Triple-super phosphate in $\mathrm{kg} / \mathrm{ha}$. required to saturate the fresh and dried muds to depth of $5 \mathrm{~cm}$.

\begin{tabular}{lllll}
\hline Soil Types & Fresh-Mud & $\mathrm{pH}$ & Dried-Mud & $\mathrm{pH}$ \\
\hline Mud-clay & 6.05 & 6.4 & 3.6 & 5.6 \\
Cat-clay & 3.52 & 3.5 & 4.1 & 3.3 \\
Swamp & 1.30 & 5.9 & 1.05 & 5.3 \\
mud & & & & \\
\hline
\end{tabular}

The distribution of immobilized phosphate in the phosphate-treated muds

Table 3 shows the distribution of immobilized phosphorus in the fresh muds immediately after adding potassium dihydrogen phosphate at the rate of $122 \mathrm{~kg} / \mathrm{ha}$
$\mathrm{P}_{2} \mathrm{O}_{5}$. A comparison of the values given in Table 3 with the relevant values for the unfertilized fresh muds given in Table 1 show that in the mud-clay, added phosphorus behaved differently according to the type of soil and forms of phosphorus. 
Table 3: The distribution of inorganic phosphorus in the fresh muds, immediately after adding potassium dihydrogen phosphate at the rate of $122 \mathrm{~kg} / \mathrm{ha} \mathrm{P}_{2} \mathrm{O}_{5}$.

(Results as $\mathrm{mg} / \mathrm{kg} \mathrm{P} \mathrm{P}_{5}$ oven-dry mud)

\begin{tabular}{llll}
\hline Forms of P & Mud-clay & Cat-clay & Swamp-mud \\
\hline Saloid-bound & 0 & 18 & 0 \\
Ca-bound & 165 & 10 & 12 \\
\hline Total & 165 & 28 & 12 \\
\hline
\end{tabular}

\section{Depth of Penetration of $P$}

Taking into consideration that the phosphate was applied in solution and that the muds were by no means as compact as they are under actual field conditions, the degree of penetration was surprisingly small.
It was found that soluble phosphate applied as a solution to columns of air-dried swamp mud and catclay, the depth of penetration was about $2.0 \mathrm{~cm}$. Thus, over $75 \%$ of phosphate was held in the first $2 \mathrm{~cm}$ depth and less than $50 \%$ in the top $5 \mathrm{~cm}$.

Table 4: The average distribution of immobilized phosphate with depth in paddy field which had received $122 \mathrm{~kg} / \mathrm{ha} \mathrm{P}_{2} \mathrm{O}_{5}$.

(Results as $\mathrm{mg} / \mathrm{kg} \mathrm{P} \mathrm{O}_{5}$ oven-dry mud)

Fresh mud

Forms of phosphorus

\begin{tabular}{lllllll}
\hline Depth $(\mathrm{cm})$ & $\mathrm{pH}$ & Saloid bound & Ca-bound & Occluded & Organic & Total \\
\hline $0-1$ & 6.0 & 0 & 25 & 125 & 210 & 360 \\
$1-2$ & 6.3 & 0 & 12 & 95 & 195 & 290 \\
$2-5$ & 6.4 & 0 & 6 & 89 & 151 & 146 \\
$5-8$ & 6.3 & 0 & 4 & 58 & 146 & 208 \\
$8-10$ & 6.2 & 0 & 2 & 45 & 143 & 190 \\
$10-15$ & 6.2 & 0 & 2 & 42 & 148 & 192 \\
\multicolumn{2}{l}{ Air-Dried Mud* } & & & & & \\
\hline
\end{tabular}

$\begin{array}{lllllll}0-1 & 5.7 & 0 & 35 & 137 & 215 & 387 \\ 1-2 & 5.4 & 0 & 26 & 110 & 175 & 311 \\ 2-5 & 5.1 & 0 & 8 & 106 & 145 & 259 \\ 5-8 & 4.8 & 0 & 4 & 85 & 136 & 225 \\ 8-10 & 4.9 & 0 & 0 & 62 & 130 & 192 \\ 10-15 & 4.6 & 0 & 0 & 60 & 132 & 192\end{array}$

${ }^{*}$ Based on a drying period of 15 days

Table 4 gives the average distribution of the forms of immobilized phosphate down the profile for those paddy fields which had received $122 \mathrm{~kg} / \mathrm{ha} \mathrm{P}_{2} \mathrm{O}_{5}$ as Triple-super phosphate. The fractionation analysis was performed on the same cores on the dried mud after 5 days. It was observed that the $\mathrm{pH}$ of the dried mud continued to fall due to continuing oxidation of the air-dried mud as shown on Table 5 and are therefore due to the slightly longer storage period.
Changes in the forms of added phosphorus when the muds are incubated under water logged conditions

The forms in which immobilized phosphorus appeared in the water-logged swamp mud, cat-clay and mud-clay after various periods of time are shown in Table 5. Immediately after the addition of $122 \mathrm{~kg} / \mathrm{ha} \mathrm{P}_{2} \mathrm{O}_{5}$ (Tripple-Super phosphate) as potassium dihydrogen phosphate, to the muds, calcium-bound phosphate decreased slightly. Occluded phosphate increased in amount in the swamp mud and cat-clay but decreased slightly in the mud-clay. Organic phosphate showed no change in the swamp mud, but decreased in the cat-clay and mud-clay. Saloid-bound phosphate was only present in the cat-clay. 
Table 5: Changes with time in forms of immobilized phosphorus in phosphate treated fresh paddy field mud, cat-clay and mud-clay.

(Result in $\mathrm{mg} / \mathrm{kg} \mathrm{P} \mathrm{P}_{5}$ oven-dry mud)

\begin{tabular}{|l|l|l|l|l|l|l|l|l|l|l|l|l|l|l|}
\hline Time & \multicolumn{3}{l}{ Saloid-bound } & \multicolumn{3}{l|}{ Ca-bound } & \multicolumn{3}{l|}{$\begin{array}{l}\text { Occluded } \\
\text { phosphate }\end{array}$} \\
\hline & $(1)$ & $(2)$ & $(3)$ & $(1)$ & $(2)$ & $(3)$ & $(1)$ & $(2)$ & $(3)$ & \multicolumn{2}{l|}{ Organic phosphate } & $(2)$ & $(3)$ \\
\hline $\begin{array}{l}\text { Before- } \\
\text { addition of } \\
P\end{array}$ & 0 & 0 & 0 & 10 & 8 & 140 & 110 & 105 & 195 & 55 & 94 & 220 \\
\hline $\begin{array}{l}\text { After } \\
\text { addition of } \\
P\end{array}$ & 0 & 45 & 0 & 7 & 6 & 135 & 125 & 122 & 182 & 54 & 75 & 215 \\
\hline 1 month & 0 & 8 & 0 & 16 & 10 & 122 & - & - & - & - & - & - \\
\hline 2 month & 0 & 6 & 0 & 25 & 12 & 155 & - & - & - & - & - & - \\
\hline 3 month & 0 & 7 & 0 & 22 & 10 & 140 & - & - & - & - & - & - \\
\hline 4 months & 0 & 6 & 0 & 20 & 10 & 135 & - & - & - & - & - & - \\
\hline 5 months & 0 & 5 & 0 & 18 & 8 & 132 & - & - & - & - & - & - \\
\hline 6 months & 0 & 4 & 0 & 16 & 7 & 130 & 104 & 125 & 240 & 56 & 90 & 220 \\
\hline
\end{tabular}

KEY

(1) - fresh paddy field mud

(2) - cat-clay

(3) - mud-clay

Occluded phosphate decreased in amount in the swamp mud, but increased in the cat-clay and mudclay. Organic phosphate showed little change in the swamp mud, and mud-clay but increased in the cat-clay over the incubation period. In the cat-clay, Saloid-bound phosphorus decreased sharply during the first month and thereafter showed little change.

The occluded phosphate in the swamp mud and cat-clay also showed a decrease within 6 months, while there were increases in the values for calcium and organic phosphate. Saloid-bound phosphorus in the water logged cat-clay decreased in value within 6 months period.

It was found that the total phosphorus in combination with the inorganic forms and the amount of occluded phosphate present was less in the limed than unlimed muds and that there was a corresponding decrease in the fixation capacity of the former mud.

The fixation capacity of phosphorus observed has shown the rapidity with which any added inorganic fertilizer-phosphorus will be immobilized. It is apparent that more phosphorus could be fixed by the swamp mud and mud-clay.

\section{DISCUSSION}

A similar exchange of phosphorus between the different organic forms of phosphate had earlier been reported by several researchers (Hesse 1963, Havlin et al 2006, Ubi and Osodeke 2007)

It has been shown that drying the fertilized paddy mud about $2 \mathrm{~cm}$ of the profile, caused a decrease in the amount of organically bound phosphorus and increase in calcium-bound phosphorus and occluded phosphate. The phosphorus in the unfertilized local acid sulphate soil was largely in the organic and occluded

forms. According to Friend and Birch, (1960), organic phosphorus is the most important source of the element to crops, but no ready mineralization of organic phosphorus results when the phosphate-treated muds are incubated.

Drying the unfertilized muds caused a fall in the soil $\mathrm{pH}$ values and occlusion of inorganic phosphate in the swamp mud and mud-clay. The difference between the behaviour of the fertilized and unfertilized swampmud on drying, suggests that the amount of phosphate occluded may be insufficient to mask the exchange reactions, if sufficiently large amounts of phosphate are present for chemical combination.

These results to date show that the total phosphorus in combination with the inorganic forms and the amount of occluded phosphate present is less in the limed than unlimed muds, and that there is a corresponding decrease in the fixation capacity of the former mud. The effect of liming is to reduce the amount of extractable aluminum and iron and when lime is combined with phosphate, the reduction effect of aluminum and iron are enhance, (FA0, 1998). The observed immobility in the amount of added fertilizer to the ponds was earlier reported (Clarkson 1996, Halvin et al 2006).

It is expected that the changes in the forms of immobilized phosphate produced by drying may to some extent be reversed by prolonged water-logging. These results are similar to those of Chang and Chu (1961), Moorman (1963), Hue and Amien (1990) and Enwezor and Moore (1996).

\section{CONCLUSION}

The most significant change which occurred on incubating the water-logged dried muds, was the 
decrease in the amount of occluded phosphate in the mud-clay. Phosphate in the swamp-mud and cat-clay also showed a decrease throughout the experimental period. Equally, the values for calcium and organic phosphate showed an increase while Saloid-bound phosphorus in the water logged cat-clay decreased in amount during the period of study. The soils have great opportunities in rice production if good soil management is enhanced.

\section{REFERENCES}

Abruna, F., Pearson, R. W. and Perez, E., 1975. Lime response of Corp and uttisols of Puerio Rico In: Soil Management in Tropical America (Edition, Bomemisya E. and Alvaredo) Rakigh, NC. North Carolina state.

Ahu, P. M., 1993. Tropical sciences and fertilizer use. Longman scientific Technical. UYC.

Brady, N. C. and Weil, R. R., 1999. The nature and properties of soils $12^{\text {th }}$ edition. Prentice, Hall, New Jersey.

Brandam K. M. S., Chandrasekaran, S. and Arunachlam, G., 1985. Effect of lime on exchangeable a luminium, nodulation and yield of peanut (Arachis hypogaea $\mathrm{L}$ ) in an acid oxisol. Tropical Agriculture (Trunidad) 62: $39-45$.

Chang, S. C. and Jackson, M. L., 1957. Fractionation of soil phosphorus. Soil Science, 84, 133.

Chang, S. C. and Chu, W. K., 1961. The fate of soluble phosphate applied to soils.

Clarkson, D. T., 1996. Excess of aluminum Plant and Soil. 27: $344-347$.

Edelman, C. H. and Van, S. and Staveren, J. M., 1958. Marsh soils in the United States and Netherlands. J. Soil and water conservation, 1 2.

Enwezor, W. O. and Moore, A. N., 1996. Phosphorus status of some Nigerian soils. Soils Sc. 102: 322 -328 .
Friend, M. T., and Birch, H. F., 1960. Phosphate responses in relation to soil tests and organic phosphorus. J. Agric. Sci. 54, 341.

F. A. O., 1998. Production year Book. Food and Agric. organization 44: F. A. O statistics series No: 99, Rome.

Havlin, J. L., Beaton, J. D., Tisdale, S. L. and Nelson, W. L., 2006. Soil fertility and fertilizers. An introduction to Nutrient Management, $7^{\text {th }}$ edition. $52-53$.

Hesse, P. R., 1963. Phosphorus relationships in a mangrove swamp mud with particular reference to aluminum toxicity. Plant and soil, 19, $205-$ 209.

Hue, N. V. and Amien, W., 1990. Alumimuim detoxication with green manure. Communication of Soil Science and Plant analysis 20: 144 1511.

Larsen, J. E., Warren, G. F. and Langton, R., 1959. Effect of iron Aluminum and humic acid on phosphorus fixation by organic soil. Soil Science Society, Amer. Proc. 23, 438 - 441.

Moorman, F. R., 1963. Acid sulphate soils (Cat-clay) of the tropics. Soil Sci., 95(4) 271.

Pearson, P. J., 1993. A technique for determination of soil tolerance of Rice. Int. Rice Communication Newsletter.

Ubi, W. and Osodeke, V. E., 2007. Root Activity pattern of Pineapple (Ananas corrosions) determined with radioactive phosphorus during the dry season Global Journal of Pure and Applied Sciences 13(4): $463-468$.

Ubi, W. and Osodeke, V. E., 2007. Toxicity of Aluminum to Pineapple (Ananas comosus) planted in acid sands of Cross River State, Global Journal of Environmental Sciences (6)1: 5- 19.

Van de Spek J., 1950. Katteklei. Verslag. Landbouwk Ondersvek. 56(2):1 - 6 